Int. J. Morphol.,

31(3):894-898, 2013.

\title{
Morphology of the Cement-Enamel Junction (CEJ), Clinical Correlations
}

\author{
Morfología de la Unión Amelo-cementaria (UAC), Correlaciones Clínicas
}

Ignacio Roa*; Mariano del Sol*,**** $\&$ Johan Cuevas $^{* * * * *}$

ROA, I.; DEL SOL, M. \& CUEVAS, J. Morphology of the cement-enamel junction (CEJ), clinical correlations. Int. J. Morphol., 31(3):894-898, 2013.

SUMMARY: The following study describes the mineralized tissue distribution which composes the cement-enamel junction, in a simple of Chilean people, comparing several teeth surfaces. Cervical area was observed (M-V, D-V, M-L/P, D-L/P sites) from 136 $(n=68)$ longitudinal sections on premolars and incisors, with orthodontic or prosthetic reasons for exodontia, which were analyzed by optical microscope in order to identify the type of cement-enamel junction. For that measurement it was Choquet's criteria, founding four types: 1) cement over enamel, 2) enamel over cement, 3) vis a vis, 4) Gap presence between enamel, cement and exposed dentin. The objective of this study was to determine the prevalence of these. As result, it was observed that there was no association between tooth surface and Choquet's classification; however that association was observed while comparing the type of tooth and the relationship with mineralized tissues at the CEJ. So, incisors were associated with class 1 and premolars with class 3 of Choquet. Class 3 prevalence is the most frequently observed in the sample size $(51.9 \%)$, following class $1(42.4 \%)$, class $4(4.4 \%)$, and class 2 with the lower prevalence on the sample $(1.5 \%)$. Because this region is fragile and highly susceptible to pathological changes and from the external environment, it must be carefully handled during clinical procedures such as teeth whitening, orthodontics, restorations, root scaling and clamp placement.

KEY WORDS: Enamel; Cement; CEJ; Clinical aspects.

\section{INTRODUCTION}

Cement - Enamel Junction is the anatomical boundary between enamel on tooth crown and the cement which covers the root of the tooth. (Franchischone, 2006; Franchischone \& Consolaro, 2008). It is an important benchmark in clinical dentistry, because is the place where gingival fibers are attached to a tooth in a healthy state; so, it is the reference benchmark in order to assess periodontal destruction (Hu et al., 1983; Berendregt et al., 2009).

Choquet (1899) was the first one to describe the relationship between enamel and cement at the UAC (CEJ), describing four types of relations between those tissues: 1) cement over enamel, 2) enamel over cement, 3) vis a vis, 4) Gap presence between enamel, cement and exposed dentin. This classification was named for his work, and has been studied for years using several methods including observation, light microscope (Arambawatta et al., 2009), scanning electron microscopy (Neuvald \& Consolaro, 2000), and morphogenic and embryological analysis (Owens, 1976; Bosshardt \& Schroeder, 1996).
Derived from these analyses several prevalence and results emerge, which are contradictory to those found by Choquet. Some authors even found enamel not covering cement (Aguirre et al., 1986; Gómez de Ferraris \& Campos, 2008). This may be induced on odontogenesis stages; were enamel is secreted prior to cement. (Mjör \& Fejerskov, 1986; Abramovich, 1999).

In the world, every day is a greater tendency towards population aging and thus and increase on the CEJ participation in the restorative and exposed area on periodontal disease; that is why it has become an area of increasing interest because of the cervical and radicular caries increased prevalence associated with abfraction and abrasion lesions, and the increased tooth sensitivity (Bevenius et al., 1993; Arambawatta et al.).

In our country there are not prevalence studies of cement-enamel relationships on the CEJ, nor studies that determine association between tooth type or tooth surface with

* Unidad de Histología y Embriología; Departamento de Ciencias Básicas Biomédicas, Facultad de Ciencias de la Salud, Universidad de Talca, Chile.

** Universidad de La Frontera, Temuco, Chile.

**** Centro de Investigación en Ciencias Biomédicas, Universidad Autónoma de Chile.

***** Odontólogo, Consulta Privada. 
an specific Choquet's classification assigned, and for this reason and joined the disparity of results obtained by other authors, it is needed to study a sample in Chilean population.

\section{MATERIAL AND METHOD}

Sample. For the sample 68 permanent and healthy teeth were used (34 premolars, 34 incisors), extracted by orthodontic or prosthetic reasons from people of both genders with a age range of 13 to 35 years, obtained from public and private clinics of the VII and VIII regions of Chile, during the months of May to October of 2012.

Inclusion and exclusion criteria. Permanent incisors and premolars from both jaws were used, of both genders. Teeth should not have carious lesions, restorations, zone exposure by periodontal disease or gingival recession, which could expose $\mathrm{CEJ}$ to the oral environment.

Procedure. Once the sample was obtained, each extracted teeth was carefully cleaned with gauze and physiological saline, removing the biological material present at the level of the area to be studied, and then were stored in individual flasks with physiological saline.

Each tooth was cut longitudinally in vestibule-lingual direction (V-L) or vestibule-palatine (V-P), according to the dental piece, obtaining two samples of similar dimensions, achieving a mesial (M) and a distal (D) sample. For this procedure a $1.5 \mathrm{~mm}$ carburundum disk mounted on a Bethel CT06801 electrical micromotor was used (Foredom Electric Co. ${ }^{\circledR}$, USA). Cuts were made under continuous spray water refrigeration, to avoid damaging the tissues on study.

Before that, samples were stored in flasks with $5 \mathrm{ml}$ of black chinese ink Mars Matic ${ }^{\circledR}$ (Staedler ${ }^{\circledR}$, Germany), for three hours, in order to stain the tissues and thus easily differentiate them. Subsequently, samples were washed with potable water or 5 minutes for their immediately observation.

Once the samples were already stained, observation was now made using a stereomicroscope SZ61 (Olympus ${ }^{\circledR}$ ), at $45 x$, placing them horizontally into a black background slide. Photographs were taken of each type of cement-enamel relationship that was found, with an Arquimed ${ }^{\circledR}$ CO-3 camera.

Analysis Plan. It was registered the relationship of the tissues which composes the CEJ, observed in the M-V, D-V, M-L/P, D$\mathrm{L} / \mathrm{P}$ from the mesial and distal samples of the 68 teeth, by a doubleblind observation. The relationship of the mineralized tissues composing the CEJ was classified into four different categories:
- Cement covering enamel.

- Enamel covering cement.

- Vis a vis.

- Gap between enamel and cement, which exposes underlying dentin.

Statistical Analysis. Obtained data was entered into an Excel spreadsheet and then analyzed using the statistical program SPSS 15.0, in order to analyze the relationship between variables using Fisher's exact test.

\section{RESULTS}

From the 136 sections of the teeth $(n=68)$, obtained results were:

Choquet Cases Prevalence. On the entire sample, a 51.9\% corresponds to Choquet's Case 3, Case 1 a $42.2 \%$, Case 4 a $4.4 \%$ and Case 2 a $1.5 \%$ of the sample.

Tooth Surface v/s Choquet's Case. Four study zones are observed, and the most prevalent Choquet's classification is class 3 with percentages that goes from $48.4 \%$ in $\mathrm{M}-\mathrm{V}$ zone to $55.6 \%$ in $\mathrm{D}-\mathrm{L} / \mathrm{P}$ area, followed by class 1 with percentages from $40.6 \%$ to $44.4 \%$; then class 4 with a $2.8 \%$ in $\mathrm{M}-\mathrm{L} / \mathrm{P}$ and $\mathrm{D}-\mathrm{L} / \mathrm{P}, 6.3 \%$ on $\mathrm{D}-\mathrm{V}$ and $6.5 \%$ in $\mathrm{M}-\mathrm{V}$ zone. By last, class 2 is not present on $\mathrm{M}-\mathrm{L} / \mathrm{P}$ or $\mathrm{D}-\mathrm{L} / \mathrm{P}$ zones; only in $\mathrm{M}-\mathrm{V}$ with a $3.1 \%$ and $\mathrm{D}-\mathrm{V}$ with a $3.2 \%$

Fisher's exact test revealed no statistically significant differences regarding the association between observed tooth face and Choquet case.

Tooth type v/s Choquet's Case. It was observed that central and lateral upper incisors, and lateral lower incisors present Choquet's class 1 in the $100 \%$ of the cases; on the other side, lower central incisors share class 1 and 3 with a 50\% each one. In the case of premolars, both upper and lower, most prevalent Choquet's class is class 3, with a $66.7 \%$ and a $56 \%$ respectively; class 1 with $25.9 \%$ for first maxillary premolars and 36\% for first mandibular premolars. Class 2 and 4 are presented with a $3.7 \%$ for the first maxillary molar and in the case of the first mandibular molar, class 2 is not described, while class 4 is present in the $8 \%$ of the samples.

Regarding to the analysis of the association between tooth type and Choquet's specific class, Fisher's exact test showed the existence of association between the tooth type with an specific Choquet's class ( $\mathrm{p}=0.00$ ). Most important associations are as follows: class 1 for incisors and first premolars with Choquet's case 3. 


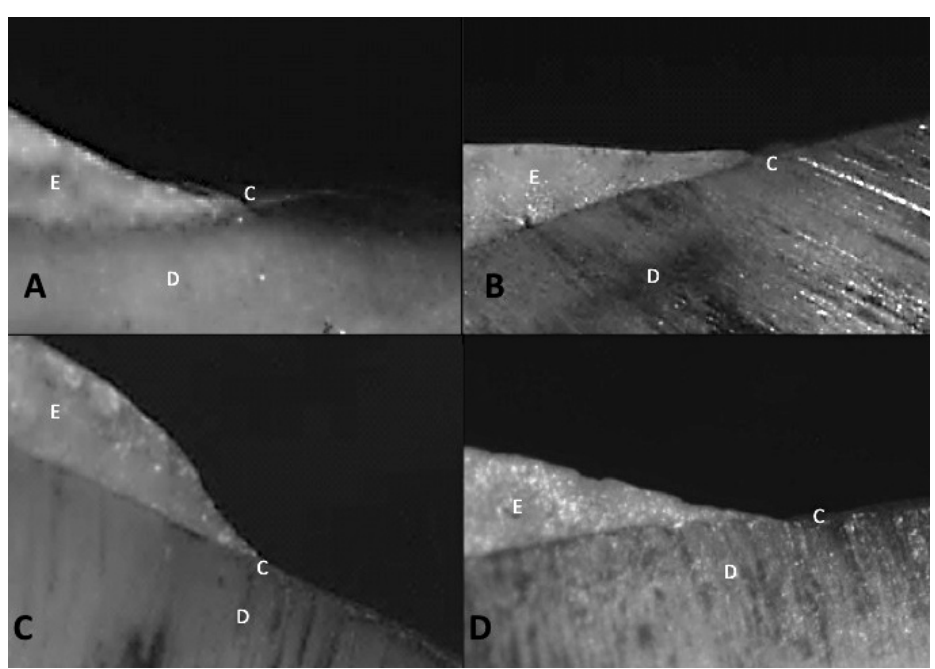

Fig. 1. Morphology of the cemento-enamel at the CEJ. A: Cement covering enamel. B: Enamel covering cement. C: Vis a vis. D: gap between two mineralized tissues. (E: enamel, D: dentin, C: cement).

\section{DISCUSSION}

CEJ morphology in permanent teeth has become an area of great clinical interest, because of its sensitivity and increased susceptibility of the dentin in the CEJ to pathological changes, such as radicular caries and non-carious lesions (Aw et al., 2002).

Vandana \& Gupta (2009) indicate that one of the most important parameters in the evaluation of the periodontal disease is the loss of connective attachment to the tooth, and is here in the CEJ, which is an static benchmark, acts to measure periodontal destruction. In young adults, the CEJ is covered by gingival tissue, however, with increasing age and the passive eruption of the tooth, which compensates the incisal and occlusal wear, and periodontal disease, can expose to the oral environment the CEJ and thereby increase the possibility that chemical and physical processes compromise it and change their morphology (Arambawatta et al.).

In the total of the observed sample, four types of cementenamel were shown at the CEJ, described by Choquet. Results shown that the vis a vis relation (class 3), was predominant for the total of the sample size with a $51.9 \%$, followed by cement covering enamel (class 1), which was presented with a $42.4 \%$ of the sample, similar to other author's results. (Muller \& van Wyk, 1984; Abramovich; Bevenius et al.).

The relationship in which there was a gap between the two tissues (class 4), appeared with a low frequency (4.4\%), compared to other classifications. Abramovich claims that this type of cementenamel relationship will be explained technical errors due to the minimum thickness of the tissues that conform this area, which could release from there and distort the observation. This affirmation is not shared by other authors who relate their presence, and also indicating that is the third most prevalent (Muller \& van Wyk; Bevenius et al.; Schroeder \& Scherle, 1998); results that are similar to those found in the present study.

Gap presence (class 4), along to the exposure of the zone, could make the tooth more susceptible to the action of the oral environment, with the increased possibility, for example, that bleaching agents could penetrate dentinal tubules, inducing inflammation, which could develop a radicular resorption process, increasing dentin sensitivity, as a prevalent consequence of bleaching treatments (Dahl $\&$ Pallesen, 2003). The gap presence could be explained in the process of the radicular formation, mainly because of the absence of disintegration of the epithelial root sheath (Hertwig), and the connective tissue will not be able to bond to dentin, leaving exposed itself (Mjör \& Fejerskov).

The presence of enamel covering cement (class 2), is controversial because there are several authors who dismiss the existence of that relationship (Aguirre et al.; Gómez de Ferraris \& Campos) considering it as an optical illusion due to the angle of the cuts made (Muller \& van Wyk). In our study and observation, this class was found in a low frequency $(1.5 \%)$, similar results to those found by Ceppi et al. (2006) and Neuvald \& Consolaro.

The existence of enamel covering part of the cement, according to some authors is embryological hard to explain, because enamel stops its secretion before cement, (Mjör \& Fejerskov; Abramovich). However, Barrancos \& Barrancos, indicate that this phenomenon is due to the existence of an overactive epithelial root sheath (Hertwig) with persistent intermediate substrate; a similar situation also happens with enamel pearls.

The relationship between cement and enamel at the CEJ, not only varies between subjects, but also between teeth from the same individual (Grossman \& Hargreaves, 1991), and even among the cuts made on the same tooth (Schroeder \& Scherle); being according to Lehmann \& Schmeisser (1991), "irregular and unpredictable in all its extension". John (2005), using ultrasound determined that CEJ has thickness variations in the different surfaces of a tooth, which may be confirmed by the description of these authors. In our observations, we noted the 
existence of multiple relationships with respect of the surfaces observed; vis a vis was presented in all dental surfaces with percentages ranged from $48.4 \%(\mathrm{M}-\mathrm{V})$ to $55.6 \%(\mathrm{D}-\mathrm{L} / \mathrm{P})$, followed by class 1 , ranged in percentages of $40.6 \%(\mathrm{D}-\mathrm{V})$ to $44.4 \%(\mathrm{M}-\mathrm{V})$. In M-L/P and D-L/P surfaces were not observed cement-enamel relationships, where enamels covers cement.

Our sample consisted of teeth from women and men of different ages and both jaws, because according to studies realized by Arambawatta et al., there is no association between gender, age and jaw (maxilla/mandible) and Choquet's case; so, these variables should not alter the results.

$\mathrm{CEJ}$ is a zone that in contact with the oral environment becomes susceptible to morphological changes, induced by physical agents, such as, traumatic tooth brushing and dental instruments (curettes, jackets and clamps). Chemical agents such as teeth whiteners, highly required by patients on these days (Arambawatta et al.). Esberard et al. (2007), before its application (intra or extracameral in different concentrations), may induce detectable changes in the morphology of the CEJ. Meanwhile, Gasic et al (2012), before analyzing the changes in this area, subsequently to the application of dental bleaching agents, did not detect any alterations using scanning electronic microscopy, and it would be stable to the chemical action of these substances. Komabayashi et al. (2008) before the analysis of the density of dentinal tubules under the CEJ, established that there was no difference between tooth surfaces. Therefore, and eventually depending on present Choquet's class, bleaching agents could penetrate more or less easily to the dentinal tubules and through them affect the dental pulp.

With respect to the relationship of caries and Choquet's class, Fonseca \& Fonseca (1992), analyzed this correlation, finding that in a $15.2 \%$ of the cases, decay started on cement; $9.6 \%$ on the dentin; $9.2 \%$ on the cement-enamel junction and $2 \%$ on the enamel, so Choquet's classes 1 and 4 are the most likely to be affected by carious process. These results are concordant to the ones related by Satheesh et al., (2011), which shows that Choquet's class that accumulates more plaque are classes 1 and 4, mainly because of their structural characteristics, that increase the adhesion of the biofilm.

With respect to non-carious cervical lesions, the CEJ is the area where a higher percentage of these are initiated (Palamara et al., 2006; Hur et al., 2011) subsequently progressing in size and depth, bringing with injuries which could subsequently affect the vitality of the tooth. For Cuniberti de Rossi \& Rossi (2009), the presence of Classes 2 and 4 are certainly, along with other factors such as enamel thickness and orientation of the prisms, the most important predisposing factors for the formation of abfractions; classes that in our study obtained a lower percentage.

As has been seen, the area of the cement-enamel junction is important for several processes such as periodontal disease, caries and non-carious cervical lesions, so it is necessary new studies related to the association between tooth type and relationship between cement and enamel at the CEJ, using a larger sample for the study.

ROA, I.; DEL SOL, M. \& CUEVAS, J. Morfología de la unión amelo-cementaria (UAC), correlaciones clínicas. Int. J. Morphol., 31(3):894-898, 2013.

RESUMEN: Se describe la distribución de los tejidos mineralizados que componen la unión amelocementaria de una muestra de la población chilena, con respecto a distintos dientes y distintas caras de éste. Se observó la región cervical (zona M-V, D-V, M-L/P, D- L/P) de 136 (n=68) secciones longitudinales de premolares e incisivos, con indicación de extracción por razones ortodónticas o protésica, los cuales fueron analizadas mediante lupa estereoscópica para identificar el tipo de relación cemento-esmalte. Fue utilizada para dicha observación los criterios de Choquet; así se observaron cuatro tipos: 1) Cemento sobre esmalte; 2) Esmalte sobre cemento; 3) Bis a bis y 4) Presencia de brecha entre el esmalte y cemento con la dentina expuesta. Se observó que no existía asociación entre caras del diente y la clasificación de Choquet, en cambio sí existió dicha asociación entre el tipo de diente y la relación de los tejidos mineralizados en la UAC. De esta manera, los incisivos se asocian con la clase 1 y los premolares con la clase 3 de Choquet. En cuanto a la prevalencia, la clase 3 era la más frecuente en el total de la muestra (51,9\%) seguido de la clase 1 (42,2\%), de la clase $4(4,4 \%)$ y la clase 2 fue observada en una pequeña proporción de la muestra $(1,5 \%)$. Debido a que esta región es frágil y altamente susceptible a cambios patológicos y del medio externo debe ser manejada cuidadosamente durante procedimientos clínicos como el blanqueamiento dental, tratamiento de ortodoncia, restauración, destartraje o colocación de clamps.

PALABRAS CLAVE: Esmalte; Cemento; UAC; Aspectos clínicos.

\section{REFERENCES}

Abramovich, A. Histología y embriología dentaria. $2^{\text {a }}$ ed. Editorial Panamericana, 1999.
Aguirre, A. A. et al. Histología y embriología del sistema estomatognático. Santiago, Universidad de Chile, 1986.

Arambawatta, K.; Peiris, R. \& Nanayakkara, D. Morphology of the cemento-enamel junction in premolar teeth. J. Oral Sci., 51(4):623-7, 2009. 
Aw, T.; Lepe, X.; Johnson, G. \& Mancl, L. Characteristics of noncarious cervical lesions: a clinical investigation. J. Am. Dent. Assoc., 133(6):725-33, 2002.

Barrancos, M. J. \& Barrancos, P. J. Operatoria dental, integración clínica. $4^{\mathrm{a}}$ ed. Buenos Aires, Panamericana, 2006. pp. 265-80.

Bevenius, J.; Lindskog, S. \& Hultenby, K. The amelocemental junction in young premolar teeth. A replica study by scanning electron microscopy. Acta Odontol. Scand., 51:135-43, 1993.

Bosshardt, D. D. \& Schroeder, H. E. Cementogenesis reviewed: a comparison between human premolars and rodent molars. Anat. Rec., 245(2):267-92, 1996.

Ceppi, E.; Dall'oca, S.; Rimondini, L.; Pilloni, A. \& Polimeni, A. Cementoenamel junction of deciduous teeth: SEM-morphology. Eur. J. Paedia. Dent., 7:131-4, 2006.

Choquet, J. Note sur les rapports anatomiques existant chez l'homme entre l'émail et le cément. L'Odontologie., 8:115-25, 1899.

Cuniberti de Rossi, N. E. \& Rossi, G. H. Lesiones Cervicales no Cariosas. La Lesión dental del futuro. Buenos Aires, Panamericana, 2009.

Dahl, J. \& Pallesen, U. Tooth bleaching a critical review of the biological spects. Crit. Rev. Oral Biol. Med., 14:292-304, 2003.

Esbenard, R.; Esbenard, R. R.; Esbenard, R. M.; Consolalaro, A. \& Pameijer, C. H. Effect of bleaching on the cemento-enamel junction. Am. J. Dent., 20(4):245-9, 2007.

Francischone, L. Morfologia da junção amelocementária em dentes decíduos humanos na microscopia eletrônica de varredura e os efeitos da clareação externa. Tesis Doctoral. Facultad de Odontología, Universidad de Baurú, Sao Paulo, Brasil, 2006.

Francischone, L. \& Consolaro, A. Morphology of the cementoenamel junction of primary teeth. J. Dent. Child. (Chic.), 75:252-9, 2008.

Fonseca, M. M. \& Fonseca, G. M. Relación esmalte-cemento y presencia de caries. Rev. Facultad de Odontología, 19/20:1/2, 1992.

John, C. Directing ultrasound at the cement-enamel junction (CEJ) of human teeth: I. Asymmtry of ultrasonic path lengths. Ultrasonics, 43:467-79, 2005.

Gasic, J.; Kesic, L.; Popovic, J.; Mitic', A.; Nikolic, M.; Stankovic, S. \& Barac, R. Ultrastructural changes in the cemento-enamel junction after vital tooth bleaching with fluoride and fluoridefree agents - a pilot study. Med. Sci. Monit., 18(3):PR5-12, 2012.

Gómez De Ferraris, M. \& Campos Muñoz, A. Histología, embriología e ingeniería tisular bucodental. Madrid, Panamericana, 2008. pp. 113-36.

Grossman, E. \& Hargreaves, J. Variable cement-enamel junction in one person. J. Prosthet. Dent., 65(1):93-7. 1991.

Hu, H.; Hof, M.; Spanauf, A. \& Renggli, H. Validity of clinical assessments related to the Cemento-enamel junction. J. Dent. Res., 62(7):825-9, 1983.

Hur, B.; Kim, H.; Park, J. \& Verslius, A. Characteristics of non-carious cervical lesions an ex vivo, study using micro computed tomography. J. Oral Rehabil., 38:469-74. 2011.

Komabayashi, T.; Nonomura, G.; Watanabe, L. G.; Marshal, Jr. G. W. \& Marshall, S. J. Dentin tubule numerical density variations below the CEJ. J. Dent., 36(11):953-8, 2008.

Lehmann, U. \& Schmeisser, S. Variations of cemento-enamel junction of human teeth. Literature review. Dtsch Stomatol., 41(12):5169, 1991.

Muller, C. J. M. \& van Wyk, C. W. The amelocemental junction. J. Dent. Assoc. S. Afr., 39:799-803, 1984.

Mjör, I. \& Fejerskov, O. Human Oral Embryology and Histology. Copenhagen, Munksgaard, 1986.

Neuvald, L. \& Consolaro, A. Cementoenamel junction: microscopic analysis and external cervical resorption. J. Endod., 26(9):5038, 2000 .

Owens, P. The root surface in human teeth: a microradiographic study. J. Anat., 122(2):389-401, 1976.

Palamara, J. E.; Palamara, D.; Messer, H. H. \& Tyas, M. J. Tooth morphology and characteristics of non-carious cervical lesions. J. Dent., 34(3):185-94, 2006.

Satheesh, K.; MacNeill, S. R.; Rapley, J. W. \& Cobb, C. M. The CEJ: a biofilm and calculus trap. Compend. Contin. Educ. Dent., 32(2):30, 32-7; 2011.

Schroeder, H. E. \& Scherle, W. Cementoenamel junction revisited. J. Periodontal Res., 23:53-59, 1998.

Vandana, K. \& Gupta, I. 2009. The location of cemento enamel junction for CAL measurement: A clinical crisis. J. Indian Soc. Periodontol., 13(1):12-5, 2009.

Correspondence to:

Ignacio Roa Henríquez

Unidad de Histología y Embriología

Depto. Ciencias Básicas Biomédicas

Facultad de Ciencias de la Salud

Universidad de Talca

Av. Lircay $s / n$

Talca- CHILE

Email: iroa@utalca.cl

Received: 22-05-2013

Accepted: 24-06-2013 